\title{
反復照度差ステレオ法を用いた微細形状計測装置の開発
}

\author{
井本 治孝*1, 町田 賢一郎 ${ }^{* 2}$, 山浦 佑介*3, 蓼沼 周*4, 前川 卓*5
}

\section{Development of microscopic shape measuring system using iterative photometric stereo techniques}

\author{
Harutaka IMOTO $^{* 1}$, Kenichiro MACHIDA ${ }^{* 2}$, Yusuke YAMAURA ${ }^{* 3}$, Hiroshi TADENUMA ${ }^{* 4}$ \\ and Takashi MAEKAWA ${ }^{* 5}$ \\ ${ }^{* 1, * 2}$ IHI Corporation, Production Technology Dept. \\ 1 Shin-nakahara-cho, Isogo-ku, Yokohama 235-8501, Japan \\ *3,*4,*5 Department of Mechanical Engineering, Yokohama National University \\ 79-5 Tokiwadai, Hodogaya-ku, Yokohama 240-8501, Japan
}

\section{Received 18 September 2015}

\begin{abstract}
In the manufacturing process of machine products, it is important to automate the manual visual inspection in detecting microscopic surface defects in order to improve the efficiency and eliminate human errors as well. The basic hardware system consists of a high-resolution camera equipped with a telecentric lens, and a device to change light directions using 60 LED light bulbs. We introduce an accurate automatic system to detect such surface defects based on the novel hardware system and the iterative photometric stereo techniques, which iteratively improve the quality of the estimation of the surface shape. Complex examples are provided to demonstrate the effectiveness of the proposed system.
\end{abstract}

Key words : Shape measurement, Optical measurement, Image processing, Photometric stereo,

Telecentric lens, Visual inspection, Surface defect

\section{1. 緒言}

製品上の微細な傷の有無やその形状を確認する検査工程においては，検査の効率と品質の向上を目的とした自 動化が求められている。自動化の手段として，例えばマスター画像との特徵量比較による画像検査があるが，凹 凸形状や寸法の定量評価が困難である。また近年，中・小物部材の三次元非接触形状計測手法として，レーザー 変位センサーを走査させて計測する手法や，パターン光を物体に投影し，投影光の撮影画像を解析することで物 体の三次元形状を計測する手法(アクティブステレオ法)を用いた装置が製造工程においても適用されつつある.

しかしこれらの手法は，レーザー光の形状（スポット径やライン幅）もしくはパターン光の投影模様以上の分解 能を実現することが基本的に困難であるとともに，物体への投影光が解析画像に鮮明に写っている必要があるた め, 投影光を十分なコントラストで撮影できない表面性状を持った物体 (鏡面や黒体) の計測に弱い傾向がある.

そこで検査の自動化を目的として，照度差ステレオ法（Photometric Stereo, Woodham, 1980）を用いた微細形状 計測装置を開発した．開発した計測装置を用いて物体の三次元形状を復元する過程を図 1 に示す．装置内に固定 設置した複数の光源を順に点灯させながら撮影した画像（図 1(a)）から，照度差ステレオ法を用いて画素単位で 物体表面の法線を算出する。図 1(b)は算出した法線の方向を色で表現した法線マップである。その後，算出した 法線から B-spline 曲面を用いて三次元形状を復元する（Yamaura et al., 2015, 図 1(c))．レーザー変位センサーを用

\footnotetext{
No. 15-00512 [DOI: 10.1299/transjsme.15-00512], J-STAGE Advance Publication date : 5 February, 2016

*1 正員，（株） IHI 生産技術センター（†235-8501 神奈川県横浜市磯子区新中原町 1)

*2（株） IHI 生産技術センター

*3 横浜国立大学大学院 工学府（干240-8501 神奈川県横浜市保土ヶ谷区常盤台 79-5)

*4 学生員, 横浜国立大学大学院 工学府

*5 正員, フェロー, 横浜国立大学大学院 工学研究院

E-mail of corresponding author: harutaka_imoto@ihi.co.jp
} 


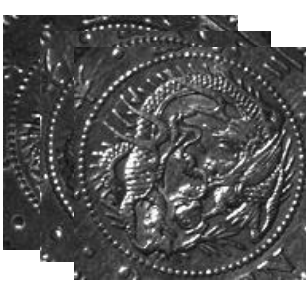

(a)

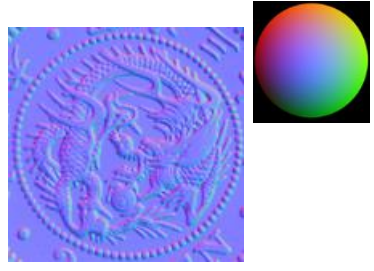

(b)

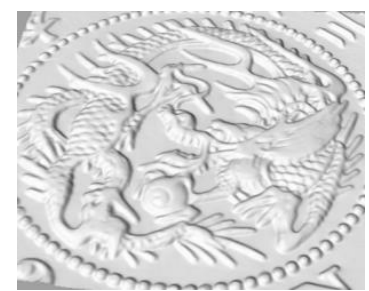

(c)

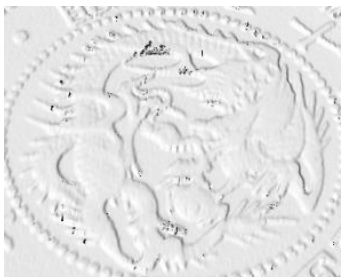

(d)

Fig. 1 Reconstruction processes of a silver coin. : (a) Images of the coin taken under different lighting conditions, (b) Normal map of the coin, (c) Reconstructed surface model using our method, (d) Reconstructed surface model using laser scanning.

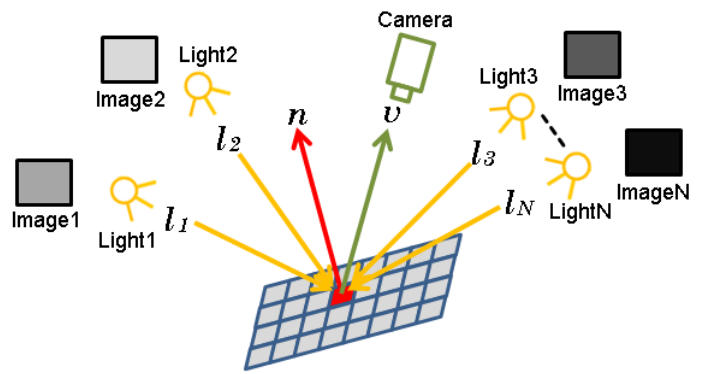

Fig. 2 Photometric Stereo

照度差ステレオ法は，視点 $\mathrm{v}$ （視線ベクトル）は固定で，異なる光源方向 $\mathbf{l}_{1} \ldots \mathbf{l}_{N}$ から順に光を照射しながら撮影 した複数枚の画像をもとに，画像に写っている物体の輝度情報から物体表面の傾き（法線ベクトル） $\mathbf{n}$ を画素単 位で推定する（Woodham, 1980, 図 2). 物体表面が理想的な拡散反射特性（ランバート拡散反射）を有する場合， 観測輝度 $\mathrm{i}$ は，アルベド $\rho$ と物体表面の単位法線ベクトル $\mathbf{n}$ と単位光源ベクトル $\mathbf{I}$ を用いて式（1）のとおり表現 される. 光源ベクトルが既知の場合, 3 か所以上の光源から得られる式を解くことで, 画素ごとに法線とアルベ ドを求めることができる．本論文では，4 か所以上の光源から得られる式（1）の連立方程式から1のムーア・ペ ンローズ一般逆行列を用いてベクトル $\boldsymbol{\rho n}$ の最小二乗解を求め, その単位ベクトル $\mathbf{n}$ とノルム $\rho$ を算出する.

$$
\mathrm{i}=\rho \mathbf{n}^{\mathrm{T}} \mathbf{l}
$$

現実には理想的なランバート拡散反射特性を持つ物体はなく, ランバート拡散反射特性と実際の反射特性との 差異ならびに鏡面反射や影の写り込みが，算出した法線の誤差要因となる．法線算出精度を向上させる手法はこ れまでにさまざまな報告があり，大きく 2 つに分類される，ひとつは，より現実に近い反射特性モデルである拡 散反射成分と鏡面反射成分との和で表現される二色性反射をベースとしたモデルの適用（Nayar et al., 1990）であ るが，複雑な計算を要する．もうひとつは，鏡面反射成分や影を分離することで法線算出精度の向上を図る手法 である，拡散反射成分のみに変換（線形化）した画像を用いて，鏡面反射や影を分離する手法（Mukaigawa et al., 2007）や，画像の色情報を用いて鏡面反射成分を除いた specular-free 画像を生成する手法 (Tan and Ikeuchi, 2005), ロバスト推定法を用いて最適なアルベドと法線を算出する手法 (Miyazaki et al., 2010), 法線と同時算出されるア ルベドのばらつきから鏡面反射を推定する手法（Coleman and Jain, 1982）などがあげられる. 本論文では後者に 分類される新たな手法として, 法線情報をもとに復元した物体の三次元形状を用いる手法を提案する.

また, 一般的な照度差ステレオ法では, 光源からの光は平行光でかつ各光源からの光の照度は等しいという仮 定のもと, 光源の方向を推定することで光源ごとに単一の光源ベクトルを決定する. しかし, 開発した計測装置 の光源は物体までの距離が約 $400 \mathrm{~mm}$ の近接光源であるため, 光源からの光は拡散光として扱う. そこで本論文 では，三次元空間における光源の位置を決定し，それをもとに算出した撮影画素ごとの光源べクトルを照度方程 式に適用することで精度向上を図る.ささら各光源の照度補正について, これまでに報告されている光の逆二乗 
則の適用（肥後他, 2010）に加え, 光源の配光特性や輝度の個体差を考慮した観測輝度補正式を提案する. これら の補正は，各種歪みの少ない両側テレセントリックレンズを用いることで容易に適用できる.

開発した計測装置ならびに処理手法を用いて計測試験を実施した結果，微細で複雑な形状を高精度に計測でき ることを確認した. 以下， 2 章で反復計算手法ならびに法線からの形状復元手法について述べる. 3 章では開発し た計測装置ならびに光源の位置と向きの算出手法について述べる. 4 章で観測輝度值の補正について, 5 章でいく つかの検証試験とその結果について述べ，6章で結言をまとめる.

\section{2. 三次元形状復元}

\section{$2 \cdot 1$ 反復計算手法}

光源から光を物体に照射すると，反射や影が生じる（図 3 (a)). 鏡面反射は，光の入射角と反射角が等しい場 合に生じる現象である. すなわち図 3 (b) において， $\theta_{1}$ と $\theta_{2}$ が一致している部分の観測輝度值には，高い比率で 鏡面反射成分が含まれていると考えられる．またアタッチドシャドウは，物体表面の法線方向と光源方向との関 係により直接光の当たらない部分に生じる陰である. 寸なわち図 3 (b) において， $\theta_{1}$ が 90 度よりも大きい場合 は，アタッチドシャドウが発生していると考えられる，つまり，光源，法線，視線の各べクトルのなす角から鏡 面反射とアタッチドシャドウの影響が強い画素を特定し，解析から除去することができる．本論文では，光源の 三次元位置が既知で物体のアルベドが均一であるととともに，対象が被写界深度の範囲内に収まる大きさで，才 クルージョンのない物体であるという前提のもと，一般的な照度差ステレオ法により算出した法線ベクトルを用 いて復元した物体の三次元形状を初期形状とし，反復計算により光源ベクトルと法線ベクトルの精度を高め，物 体の三次元形状を高精度に復元する. 以下に反復計算の手順を示寸.

（1）あらかじめ算出した光源位置（3.2節）から平行光が照射されているという想定で画像ごとに光源ベクトル を導出し，すべての画素の輝度情報を用いて照度差ステレオ法により法線ベクトルを算出する.

（2）法線ベクトルから高さを算出することで物体の三次元形状を復元する（2.2節）。ここで復元した物体の三 次元形状が以降の処理における初期形状となる.

（3）物体の三次元形状と光源位置情報をもとに光源ベクトルを算出寸る. ここでは光源からの光を拡散光として 扱い，画素ごとに光源ベクトルを算出する.

（4）光源ベクトルと法線ベクトル，視線ベクトルのな寸角から，鏡面反射とアタッチドシャドウを特定し，特定 された場所に位置する画素の情報は以降の計算に加えない手続きをとる.

（5）取得した物体の三次元形状や光源位置情報をもとに観測輝度補正式（4.5節）のパラメータを算出し, 各画 素の輝度情報に適用したうえで再度照度差ステレオ法により法線を算出し，その法線から高さを算出するこ とで物体の三次元形状を更新する.

（6）（3）から（5）を繰り返す．法線算出の際に同時算出される画素ごとのアルベドについて, 計算前後の值の

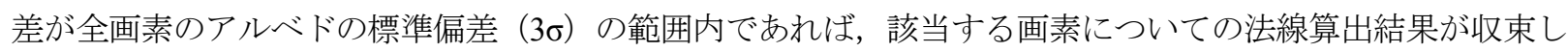
たものと判断して以降の計算から除外する。この手続きをすべての画素が収束するまで実行する.

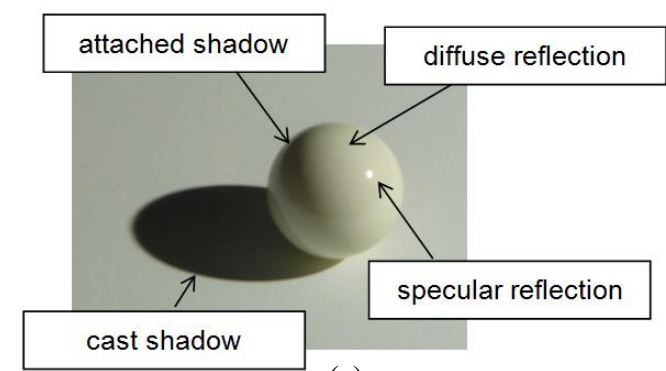

(a)

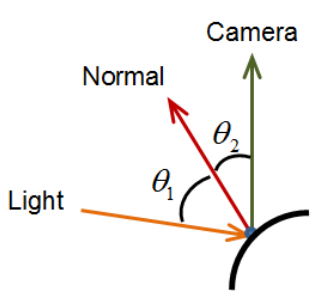

(b)

Fig. 3 Reflections and shadows : (a) The classification of reflections and shadows, (b) Angle of reflection. 
本論文では, 後述の光源位置算出精度を勘案して, $\theta_{1}$ と $\theta_{2}$ の差が 5 度以内の場合に鏡面反射の影響が強い画素 とし， $\theta_{1}$ が 85 度以上の場合にアタッチドシャドウが生じている画素として解析から除去した. また，輝度值が 1 以下の画素についてはキャストシャドウが生じている画素であると判断し，解析から除去した.

撮影画像に対して，輝度值が最小・最大值（8ビット画像の場合 0 と 255）の画素を除去した結果と，本手法を 適用した結果を図 4 に示す．本手法を適用することで，鏡面反射部分とアタッチドシャドウ部分が除去されてい ることがわかる。

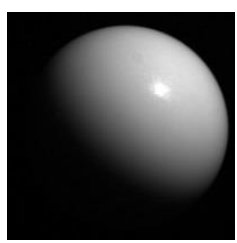

(a)

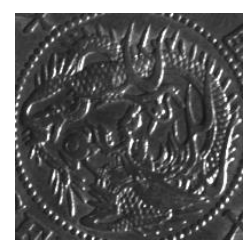

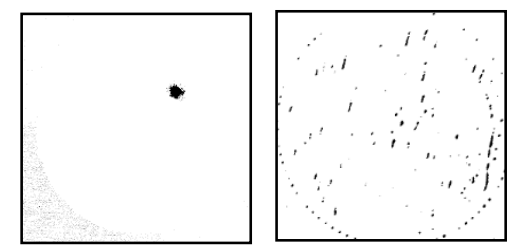

(b)

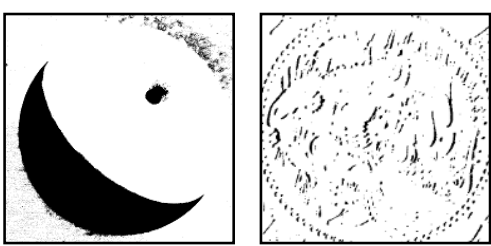

(c)

Fig. 4 Detection of specular reflections and attached shadows: (a) Original images (left: sphere, right: silver coin), (b) Results of removing minimum and maximum intensity pixels, (c) Results of our method.

本論文では，一般的な照度差ステレオ法によって得られる法線情報をもとにして復元される物体の三次元形状 を初期形状としているため，本論文で開発した装置のように光源位置が既知であれば，初期の法線が実際の法線 と比べて大幅に異なっていることはなく, その法線から復元される初期形状も大幅に異なっていることはない. ほぼ正しい形状を初期形状として用い，局所的に発生している正反射やアタッチドシャドウなどによるノイズに 対して, 法線計算の際にこれらを繰り返し除去し，その法線情報から形状を復元するため，正しい形状に収束す ると考えられる.

また，図 5 に示すように一般的に計測する物体の高さが光源との距離に対して十分小さい場合, 光源と物体と の距離 $d n$ は $d n$ 'で近似できる. 本論文では物体の高さ $h$ については被写界深度に収まる範囲であることを前提と しており, 実際の距離 $d n$ と近似された距離 $d n^{\prime}$ の差は微小である. 本論文ではより厳密に観測輝度を補正するた め二次元画素位置 $(x, y)$ に対し三次元形状復元により得られた高さ情報 $h$ を付加して距離ならびに光源ベクト ルの計算を行っているため, 三次元座標にもとづく観測輝度補正を取り入れることによって正しい形状に収束し づらくなることはないと考えられる。

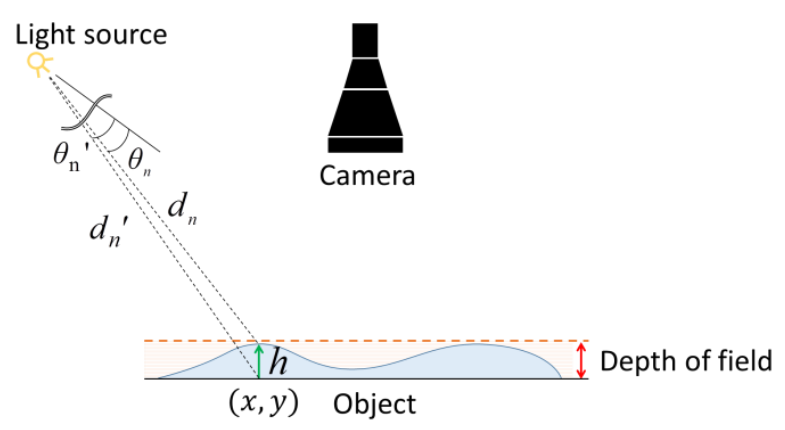

Fig. 5 The distance between the light source and the object

\section{$2 \cdot 2$ 形状復元手法}

照度差ステレオ法により算出した物体の法線ベクトルから高さを求めることで, 物体の三次元形状を復元する. 法線から高さを求める手法として, ポアソン方程式を用いた積分による手法（Horn and Brooks, 1986）や，隣り合 う画素の相対高さを円弧近似で定義するもの（Wu et al., 2008）などがある．これらは画素ごとの高さを離散的に 求めるため, 画像サイズの増加に伴うデータ量の増加や, データに接線連続が得られないといった問題がある. そこで本論文では，パラメトリック曲面を用いて物体の形状を復元した．照度差ステレオ法により算出される法 線は一様分布であることと, 正則な曲面は曲面上の任意の点の近傍において二次の高さ関数により表現可能であ ることから, 曲面表現には一様双二次の B-spline 曲面を用いた（Yamaura et al., 2015）. B-spline 曲面での復元は, 
省メモリで計算コストが低い，高精度で密な連続した形状の復元が可能，そのまま CAE・CAM 等の工程で使用 できるといった利点がある.

\section{3. 形状計測装置}

\section{$3 \cdot 1$ 装置構成}

図 6 に本論文で開発した計測装置を示す。装置上部にカメラとレンズ（図 6(a)）を光軸が鉛直下向きになるよ うに固定設置し，その下に高さが調整可能で水平な計測ステージを設置した。レンズ先端と計測ステージ面間の 距離はレーザー変位センサーで常時測定する. また, 計測ステージを中心に半径約 $400 \mathrm{~mm}$ のドーム状の枠を組 み, そこに光源として 60 個の LED モジュールを取り付けた（図 6(b)）. LED モジュールは, 内部に表面実装型 白色 LED 素子を持ち, LED 素子と平行な発光面から $\varphi 20 \mathrm{~mm}$ の白色拡散光を照射寸る. 各光源は, 発光面の寸 法が物体と光源間の距離と比較して $1 / 10$ 以下と十分に小さいため, 点光源として扱うことができる（岩永他, 2007)。また，装置全体をパネルで覆うことで環境光の混入を防いでいる（図 6(c)).

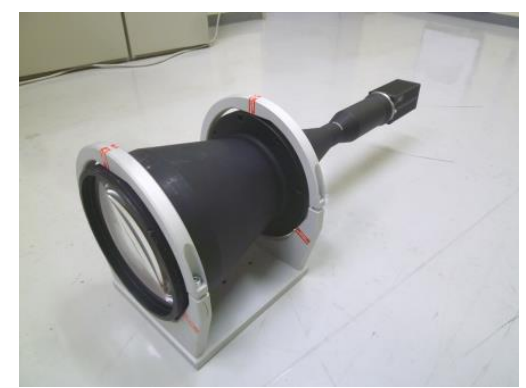

(a)

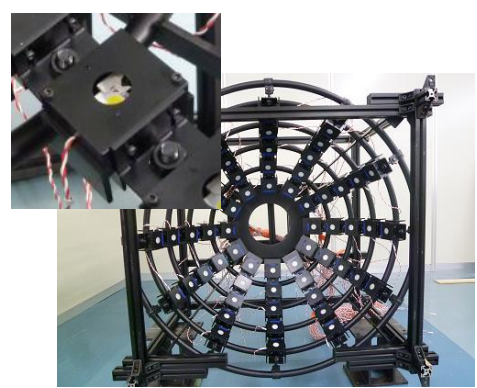

(b)

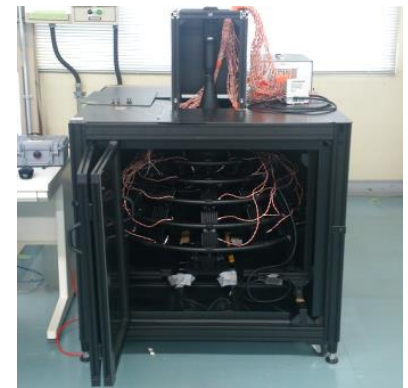

(c)

Fig. 6 Measuring system: (a) Camera and lens, (b) Layout of the LED module, (c) Appearance of the measuring system.

これまでに照度差ステレオ法を用いた装置として, 人の動きを三次元モデルで再現する装置 (Vlasic et al., 2009) や，特殊なゲルを用いた微細形状計測装置 (Johnson et al., 2011), 単一のカメラと光源によるハンディタイプの装 置（Higo et al., 2009）などさまざまな装置が報告されているが，本論文で開発した計測装置では，高精度で安定 した寸法計測の実現を目的として，両側テレセントリックレンズ（Opto Engineering TC16M120）ならびに 1600 万画素のモノクロ CCD カメラ（JAI AM1600GE）を適用した．通常のレンズでの撮影画像は透視投影画像となる のに対し, 両側テレセントリックレンズでの撮影画像は平行投影画像となる.このため両側テレセントリックレ ンズでは, 物体と光学系との間の距離が変化しても, 被写界深度 $(15 \mathrm{~mm})$ の範囲内であれば撮像面上の像の大 きさは変わらず，視差による画像歪みも生じない．これまでにも両側テレセントリックレンズを用いた装置の報 告（Hahn et al., 2006）はあるが，本論文のように両側テレセントリックレンズの特性を生かし，光源位置の決定 や，鏡面反射と影の特定を簡便に実施した報告事例はない.

\section{$3 \cdot 2$ 光源位置の算出}

本論文では，寸法が既知の複数の球体を用いた手法（Powell, 2001）を平行投影のカメラモデルに応用し，白色 セラミックス球 $(\varphi 20 \mathrm{~mm})$ を用いて, 装置座標系における光源位置を算出した（図 7(a)）。通常は事前に各球体 の位置をキャリブレーションする必要があるが，水平ステージ上に設置した球体を平行投影カメラで撮影するこ とで, 事前のキャリブレーションを不要としている. 装置座標系は, 撮影画像（水平面と平行）の中心を通る鉛 直軸上で，レンズ先端からレンズのワーキングディスタンス分離れた位置を原点とし，鉛直上方向に+Z軸，撮影 画像中心から右方向を+X軸，上方向を+Y軸としている．以下に手順を示寸．

(1) 計測ステージ上に白色セラミックス球 $(\varphi 20 \mathrm{~mm})$ を設置し, 各光源から順に投光して撮影した画像 (図 7(b)) を合成する (図 7(c)). 合成画像から, 輝度の高い領域の重心を球上の鏡面反射点として算出する. 
Imoto, Machida, Yamaura, Tadenuma and Maekawa, Transactions of the JSME (in Japanese), Vol.82, No.835 (2016)

（2）合成画像から球の中心位置と面積（単位：pixel）を算出し，既知である球の直径（20mm）をもとに，1画 素に撮影された実寸法（単位：mm）を算出する.

（3）（1）と（2）の結果から, 装置座標系における球中心ならびに球上の鏡面反射点の三次元座標值（単位: $\mathrm{mm}$ ) を算出し，2 点を通るべクトルを鏡面反射点の法線ベクトルとする.

（4）（3）の結果と視線ベクトル（平行投影なのですべて同じ）から，各光源の光源ベクトルを算出する.

（5）球の位置を変えて（1）から（4）を繰り返し実施する. 本論文では 12 回実施した.

（6）各光源に対して作成した 12 本の光源ベクトルの交点（最近点）を算出し，それを光源位置とする.

算出した各光源位置の推定誤差（最近点と各光源ベクトル間の距離の RMS 值）は $3.5 \pm 2.0 \mathrm{~mm} （ 3 \sigma)$ ，光源ベ クトルの角度誤差に換算すると最大で 0.8 度であった. また, 本手法で算出した 1 画素あたりの撮影寸法は 0.0257 mm/pixel となった（カメラのカタログ仕様と等しい）.

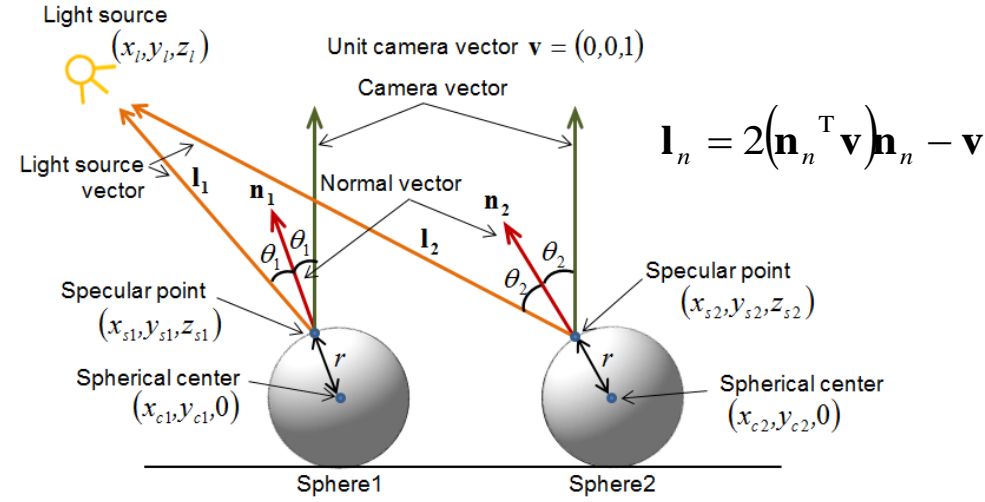

(a)

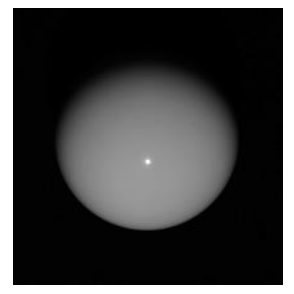

(b)

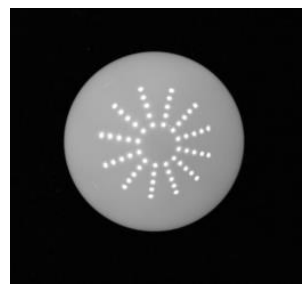

(c)

Fig. 7 Estimation of light source positions using white ceramic spheres: (a) Diagram of the light source position estimation, (b) Image of a highlighted sphere, (c) Integrated image of the sphere (60 images).

\section{$3 \cdot 3$ 光源の向きの算出}

本論文では，光源の配光特性を考慮した観測輝度值の補正を行うことを目的に，レーザートラッカー（API Radian, 精度 $\pm 5 \mathrm{ppm}$ ) を用い, 光源（LED モジュールの発光面）の位置と向きを三次元計測することで (図 8(a)), 光源の基準軸（発光面中心を通り発光面の法線と平行な軸）を算出した．計測結果はレーザートラッカー基準の 座標系であるため，レーザートラッカーによる光源位置の計測結果を， 3 ・2 節で算出した光源位置に重ね合わせ ることで，装置座標系における光源基準軸のベクトルを算出した（図 8(b)）。重ね合わせの結果，三次元座標值の

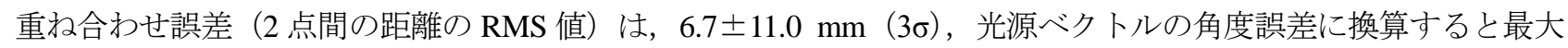
で 2.5 度であった。

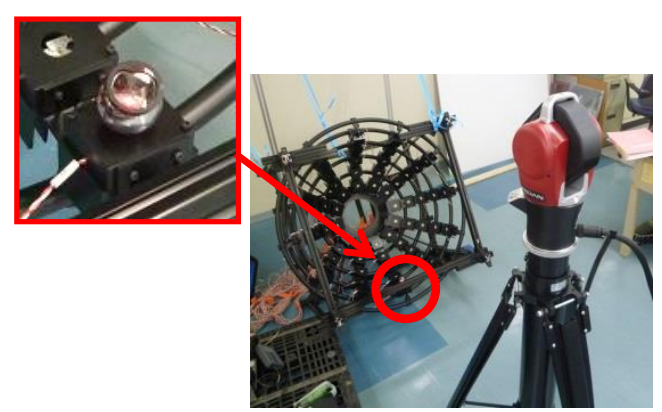

(a)

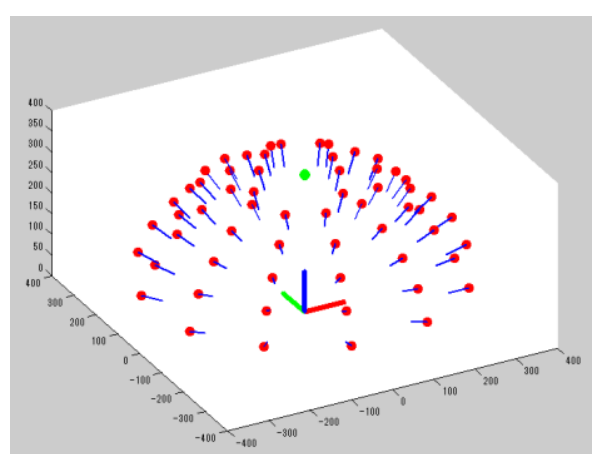

(b)

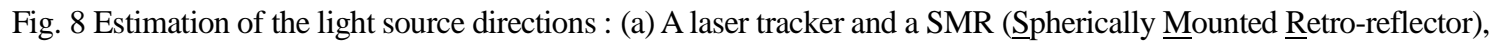
(b) Results of light positions (red dot), light directions (blue line) and the camera position (green dot). 


\section{4. 観測輝度值の補正}

\section{$4 \cdot 1$ 光の逆二乗則}

開発した計測装置の光源は，物体までの距離がそれぞれ異なる．そこで三次元空間上の光源位置と物体の三次 元形状をもとに光源と対象物間の距離を算出し，光の逆二乗則を考慮した各画素の観測輝度值の補正を行う．本 論文では, 各光源の距離 $d_{n}$ とその中の最小距離 $d_{\min }$ を用いて, 距離補正係数 $\Delta d_{n}$ を式（2）から算出した.

$$
\Delta d_{n}=d_{n} / d_{\text {min }}
$$

\section{$4 \cdot 2$ 配光特性の取得}

LED モジュールの配光特性を照度計を用いて測定した．LED モジュールを回転テーブル上に設置し，400mm 離した位置に設置した照度計と正対する向きを 0 度とした状態で, LED モジュールを発光面中心に 5 度ピッチで 回転させながら照度の值を取得した結果を図 9 に示す. $3 \cdot 3$ 節の光源向きの算出結果からの試算の結果, 各光源 において計測対象エリアを照射する光は，基準軸に対して最大 20 度の照射角度であったため， 0 度から 20 度の 実測值を式（3）に示寸点光源の配光特性の一般的なモデル式にあてはめた．ここで $I(0)$ は光源基準軸（0 度） における光度である. 結果，均等拡散光源の場合乗数 $\mathrm{k}=1$ となるのに対し今回の結果は $\mathrm{k}=1.878$ となり，指向性 を有する光源であることを確認した。

$$
I(\theta)=I(0) \cos ^{k} \theta
$$

\section{$4 \cdot 3$ カメラ逆レスポンス関数の推定}

照度差ステレオ法においては，カメラレスポンス関数（以下，レスポンス関数と呼ぶ）の非線形性が算出され る法線の誤差要因となるため, 事前にレスポンス関数の逆関数である逆レスポンス関数を求め, 観測輝度值に補 正を加える. 逆レスポンス関数の推定については，画像ノイズの分散の情報から推定する手法（高松他，2007） などの方法が提案されているが, 本論文では輝度值の制御が可能な輝度箱（壼坂電機 LSB-111TWR4）を用いた. 暗室内において輝度箱とカメラを正対させた状態で，輝度箱の発光輝度值を段階的に変化させて撮影した画像の 観測輝度值をもとに導出した逆レスポンス関数を図 10 に示寸. 本論文で用いたカメラ（AM-1600GE）に加え， 比較対象として Nikon D800 の結果も示寸. D800 がガンマ補正などの効果により非線形性を示しているのに対し AM-1600GE は線形であるが，入射輝度值が 0 である場合においても撮像素子のノイズの影響で観測輝度值が 0 ではない. 本手法で導出した逆レスポンス関数を式 (4) に示す。ここで， $i$ は観測輝度值（8ビット）である.

$$
f(i)=1.031 i-8.033 \quad \text { ( ただし } f(i)<0 \text { の場合は } f(i)=0 \text { とする })
$$

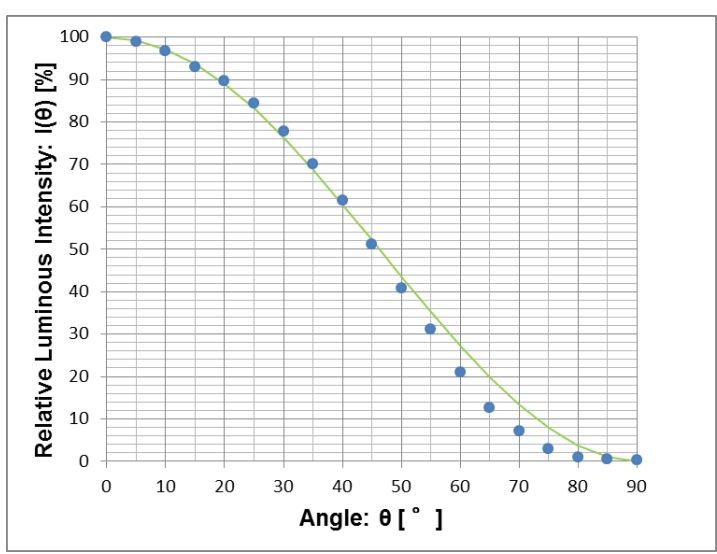

Fig. 9 Light distribution curve

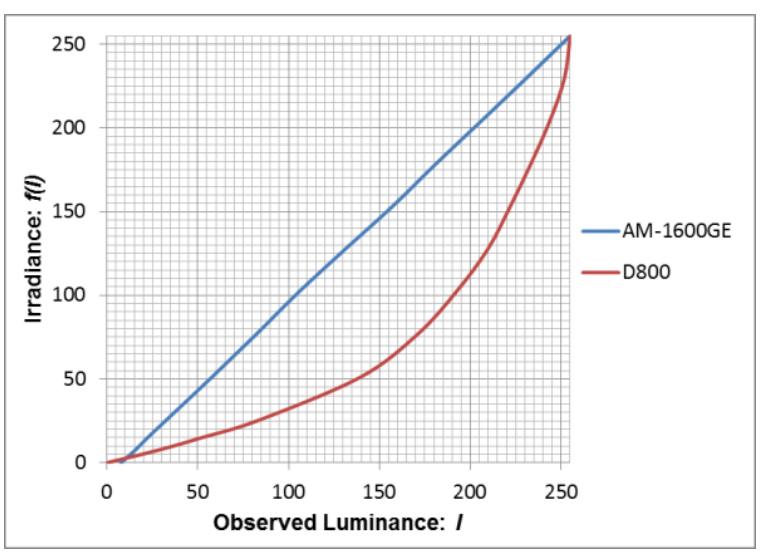

Fig. 10 Inverse response function 


\section{$4 \cdot 4$ 光源の個体差}

実際の光源は, LED の発光性能の個体差や，製作した LED 制御装置の回路損失に起因する輝度差を有する. 本論文では, 各光源の輝度を輝度計で測定し, 各光源の輝度值 $i_{i}$ と全光源における最大輝度值 $i_{\max }$ を用いて, 補 正係数 $\Delta i_{n}$ を式（5）から算出した．各光源の輝度測定の結果，平均值に対して $8 \%$ 程度のばらつきを有するこ とを確認している.

$$
\Delta i_{n}=i_{\max } / i_{n}
$$

\section{$4 \cdot 5 \quad$ 観測輝度值の補正}

上記観測輝度值の補正項目をまとめると，補正後の観測輝度値 $i_{c}$ は次式により求めることができる.

$$
i_{c}=f\left(i_{n}\right) \frac{\Delta i_{n} \Delta d_{n}}{\cos ^{k} \theta_{n}}
$$

ここで $i_{n}$ は対象画像の観測輝度值， $f$ はカメラレスポンス関数， $\Delta i_{n}$ は対象画像で使用した光源の個体差補正 係数， $\Delta d_{n}$ は対象画像で使用した光源の距離補正係数， $k$ は配光特性モデルにおける乗数， $\theta_{n}$ は対象画像で使 用した光源の基準軸 (3.3 節にて導出) と光源から対象画素への光源ベクトルとのな寸角である. 各画素に式 (6) を適用して得られた観測輝度值を反復照度差ステレオ法に適用することでより正確な法線ベクトルを得ること ができる.

\section{5. 検証試験}

\section{$5 \cdot 1$ 観測輝度值の補正の効果}

白色セラミックス製の平板 $(50 \mathrm{~mm} \times 25 \mathrm{~mm}$, 平面度 $20 \mu \mathrm{m} ）$ の三次元形状を計測し, 計測結果から算出した平 面度を評価した。照度差ステレオ法による法線算出過程において，観測輝度值に対して補正式（式（6） ）用い た補正をかける際に, 光源ベクトル, カメラレスポンス, 光源の個体差, 光源の位置ならびに光源の向きの $5 つ$ の要素について適用の有無を変えて評価を行った結果を表 1 に示寸.すべての補正を適用していない場合 (Case 1), 計測結果は平板中央部を中心に凸形状を示していたが，補正式を適用することで計測精度が大幅に向上したま た，すべての補正要素を適用した場合において 2.1 節の反復計算を適用したが効果は認められなかった．計測対 象が水平に設置した平板であり, 反復計算を行っても高さ情報は不変であったためである.

Table 1 Measurement results of the flat plate,

\begin{tabular}{|c|c|c|c|c|c|c|}
\hline \multirow[b]{2}{*}{ Case } & \multicolumn{5}{|c|}{ Correction methods } & \multirow[b]{2}{*}{$\begin{array}{c}\text { Flatness } \\
{[\mathrm{mm}]}\end{array}$} \\
\hline & $\begin{array}{l}\text { Light } \\
\text { source } \\
\text { vector }\end{array}$ & $\begin{array}{l}\text { Camera } \\
\text { response }\end{array}$ & $\begin{array}{l}\text { Individual } \\
\text { difference }\end{array}$ & $\begin{array}{c}\text { Light } \\
\text { distance }\end{array}$ & $\begin{array}{l}\text { Light } \\
\text { direction }\end{array}$ & \\
\hline 1 & - & - & - & - & - & 1.423 \\
\hline 2 & O & - & - & - & - & 1.048 \\
\hline 3 & O & ० & - & - & - & 0.912 \\
\hline 4 & ० & - & ○ & - & - & 0.835 \\
\hline 5 & ० & - & - & ○ & - & 0.066 \\
\hline 6 & ० & - & - & - & ○ & 0.839 \\
\hline 7 & 0 & o & o & o & o & 0.055 \\
\hline
\end{tabular}

"○”: Correction method used for analysis, “_”: Correction method not used for analysis. 


\section{$5 \cdot 2$ 法線算出精度の検証}

本論文で提案する反復計算と観測輝度值補正による法線算出手法 IPS（Iterative Photometric Stereo）を用いて算 出した法線の精度を検証した．比較対象として，拡散反射以外の成分をスパース回帰モデルによって分離する手 法 SBL（Sparse Bayesian Learning，Ikehata et al., 2012）ならびに，エネルギー最小化モデルから反復計算で光源方 向と法線を同時算出する未校正照度差ステレオ法 EOF（Energy Optimization Framework，Luo et al., 2015）による 法線算出結果も示す.

図 11 と表 2 は，池畑ら（Ikehata et al., 2012）が作成した 40 枚の Stanford bunny のデータセットを用いた法線算 出結果である. IPS については反復計算ごとの結果を示している. 各画像は, ランダムに設定された平行光線の 方向をもとにした鏡面反射 (Cook-Torrance モデルによる) ならびに影を合成することで作成されているため, IPS では観測輝度值補正を加えていない. SBL は輪郭部に誤差が残るものの内面の精度は高く, 輪郭部を除いた Mean error は $0.005 \mathrm{~mm}$ であった. EOF は鏡面反射部近傍に誤差が残っている傾向がある. IPS は EOFよりも高精度で あるが, 内面に誤差が残っている. また, IPS が 1 回の反復計算で収束しているのは, 本画像が平行光を想定し て作成されており, 物体の高さが変化しても光源ベクトルと物体法線との角度差が変化しないためである.

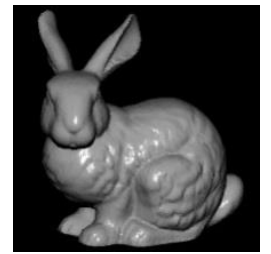

(a)

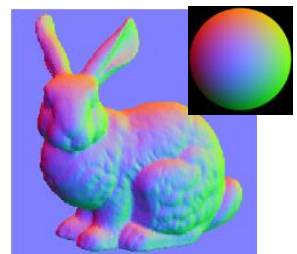

(b)

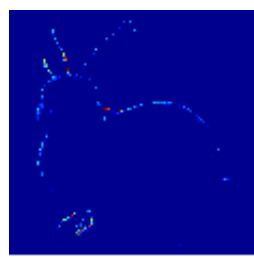

(c) SBL

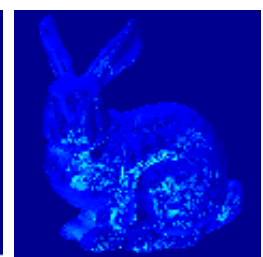

(d) EOF

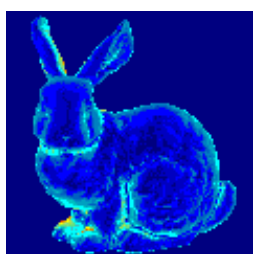

(e) IPS-1

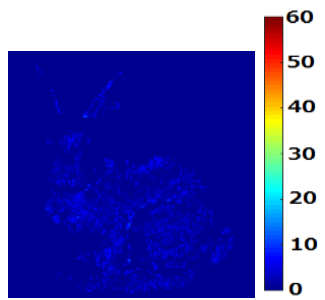

(f)IPS-2

Fig. 11 Comparison of normal estimation method: (a) Input image, (b) Ground truth of normal map, (c)- (f) Angular error maps (in degrees).

Table 2 Angular error of bunny (in degrees)

\begin{tabular}{c|c|c|c}
\hline \hline Case & Mean error & Standard deviation & Maximum error \\
\hline SBL & 0.505 & 3.630 & 68.051 \\
\hline EOF & 6.775 & 3.953 & 30.891 \\
\hline IPS-1 & 9.334 & 6.312 & 51.532 \\
\hline IPS-2 & 1.134 & 1.629 & 13.594 \\
\hline
\end{tabular}

図 12 と表 3 に, 白色セラミックス製の球（ $(920 \mathrm{~mm}$ ，面の輪郭度 $5 \mu \mathrm{m})$ を本論文で開発した計測装置で撮影し た 60 枚の画像（860×860 画素）を用いた法線算出結果を示す． IPS が最も良い精度であった．SBL と EOF は平 行光を前提とした手法であるため, 本画像のような点光源からの拡散光に起因寸る誤差が生じていると考えられ る. 処理時間について, IPS はすべての反復計算の合計で約 180 秒であった. これは, SBLに対して約 10 倍, EOF に対して約 2 倍高速である．ただし同じ PC（OS: Windows7 64bit，CPU: Intel Corei7 3.0GHz，RAM: 8.0GB）を用 いているが，プログラミング環境が異なるため純粋には比較できない（SBL と EOF は MATLAB，IPS は C++）。 本結果から，光源の位置が既知の拡散光環境下において IPS は有効な手法であるといえる.

\section{$5 \cdot 3$ 形状復元精度の検証}

5.2 節に示した IPS による白色セラミックス球の法線算出結果から三次元形状を復元し，その結果から $\varphi 20 \mathrm{~mm}$ の球面に対する面の輪郭度を評価した. 2.1 節の反復計算の実行回数を変えて評価を行った結果を表 4 ならびに図 13 と図 14 に示寸. 繰り返し計算による高さ情報を考慮した観測輝度補正ならびに鏡面反射と影の除去を行うこ とで，計測精度が向上していることがわかる. 


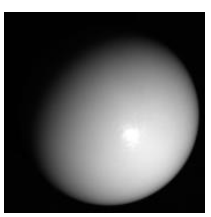

(a)

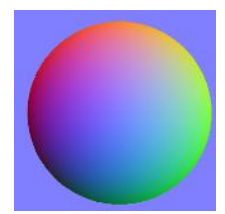

(b)

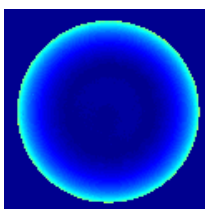

(e) IPS-1

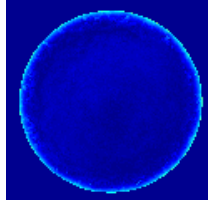

(c) SBL

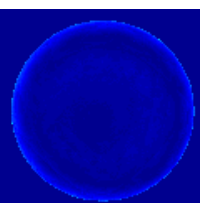

(f) IPS-2

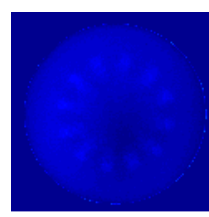

(d) EOF

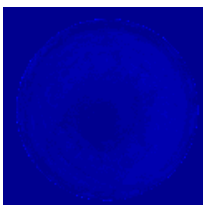

(g) IPS-3

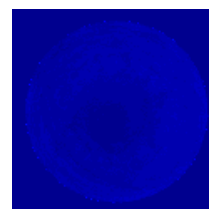

(h) IPS-4

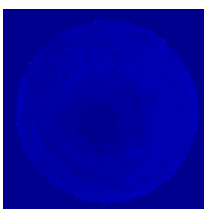

(i) IPS-5

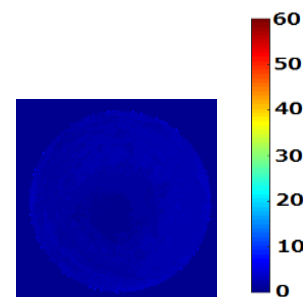

(j) IPS-6

Fig. 12 Comparison of normal estimation methods: (a) Input image, (b) Ground truth of normal map, (c)- (j) Angular error maps (in degrees).

Table 3 Angular error of sphere (in degrees)

\begin{tabular}{c|c|c|c}
\hline \hline Case & Mean error & Standard deviation & Maximum error \\
\hline SBL & 3.603 & 4.258 & 36.698 \\
\hline EOF & 3.209 & 1.342 & 28.151 \\
\hline IPS-1 & 7.980 & 7.613 & 39.030 \\
\hline IPS-2 & 2.231 & 2.290 & 27.293 \\
\hline IPS-3 & 1.629 & 0.702 & 26.451 \\
\hline IPS-4 & 1.832 & 0.672 & 26.451 \\
\hline IPS-5 & 1.848 & 0.678 & 26.451 \\
\hline IPS-6 & 1.848 & 0.678 & 26.451 \\
\hline
\end{tabular}

Table 4 Measurement results of sphere.

\begin{tabular}{c|c}
\hline $\begin{array}{c}\text { Number of } \\
\text { iterations }\end{array}$ & $\begin{array}{c}\text { Sphericity } \\
{[\mathrm{mm}]}\end{array}$ \\
\hline 1 & 4.431 \\
\hline 2 & 2.032 \\
\hline 3 & 0.716 \\
\hline 4 & 0.205 \\
\hline 5 & 0.176 \\
\hline 6 & 0.158 \\
\hline
\end{tabular}

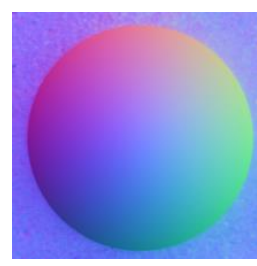

(a)

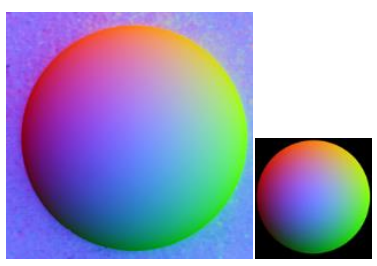

(b)

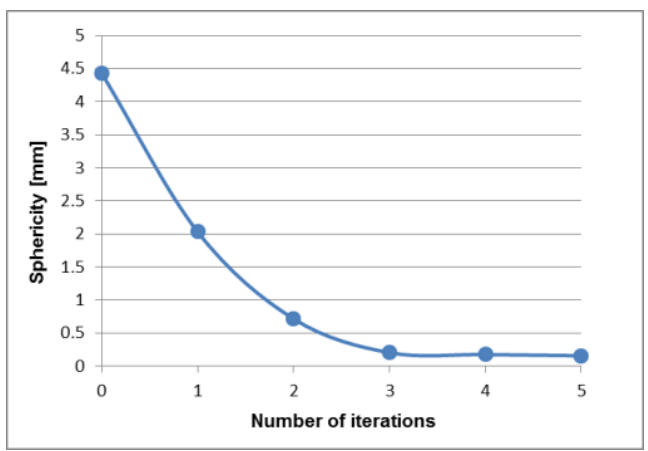

Fig.13 Effectiveness of iterations.

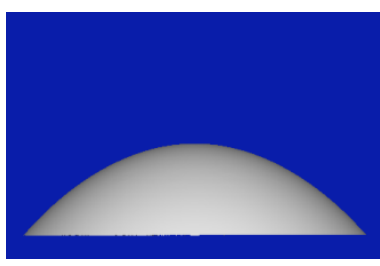

(c)

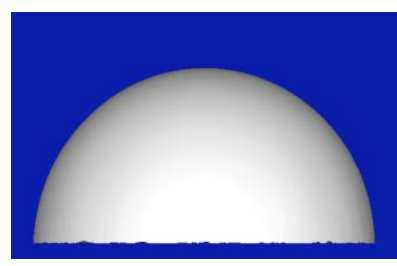

(d)

Fig. 14 Reconstruction results of sphere. : (a) Normal map of Case 1, (b) Normal map of Case 6, (c) Reconstructed surface model of Case 1, (d) Reconstructed surface model of Case 6. 
図 15 は銀貨（図 1, 図 4 と同じもの）の反復計算の過程における形状の変化を示している. 図 15(a)が観測輝 度補正をまったく行っていない場合, 図 15(b)が 1 回の反復計算を, 図 15(c)が 2 回の反復計算を行った場合であ り，それぞれ 4 回の反復計算結果に対寸る高さの差をコンター図で示している. 観測輝度補正ならびに反復計算 による計測形状の収束過程がわかる.

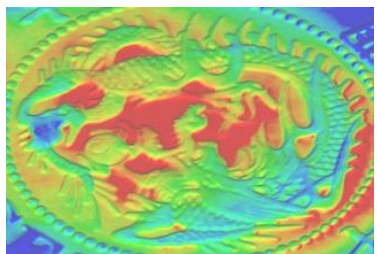

(a)

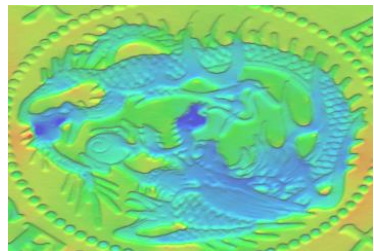

(b)

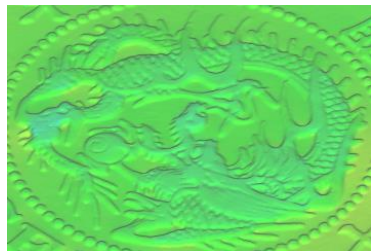

(c)

Fig. 15 Color coded error of the silver coin: (a) One time execution without any adjustment, (b) One time execution with all the adjustments, (c) Two time execution with all the adjustments, color bar in [mm].

\section{$5 \cdot 4$ 微細形状の計測}

図 16 にステンレス板の溶接ビード（長さ $100 \mathrm{~mm}$ ）の形状を計測した結果を示す．ビード形状ならびに，ビー ド周辺のスパッタや人為的に作成した打痕の形状が精細に計測できている. 半球形のスパッタ (図 16(e)の画像左 側のスパッタ）の直径は 0.172mm であり, デジタルマイクロスコープ (キーエンス VHX-600) での結果 $0.195 \mathrm{~mm}$ に対して，0.023 mm の差があった．装置の分解能 $(0.0257 \mathrm{~mm})$ を勘案すると妥当な結果であるといえる.

\section{6. 結 言}

本論文では，テレセントリックレンズと多数の光源を用いた反復照度差ステレオ法による計測装置を開発する とともに，物体高さを考慮した反復計算による鏡面反射とアタッチドシャドウの除去手法ならびに，平行投影モ デルが成立するテレセントリックレンズの特長を生かした観測輝度值の補正手法を考案し，試験によりその有効 性を確認した．算出した光源位置や光源方向ならびに反復計測中に復元した三次元形状に含まれる誤差が計測精 度に及ぼす影響については今後引き続き検証する，また，計測手法のさらなる高精度，高精細化のために，LED 輝度の個体差やテレセントリックレンズの歪曲収差や色収差の補正，キャストシヤドウの除去手法やアルベドが 均一であるという前提を必要としない反復計算の収束判定方法についても今後検討する. オクルージョン対策も 検討課題であり，これについては三次元スキャナなど別の計測手法と照度差ステレオ法とのハイブリッド計測の 適用が考えられる（Nehab et al., 2005）。

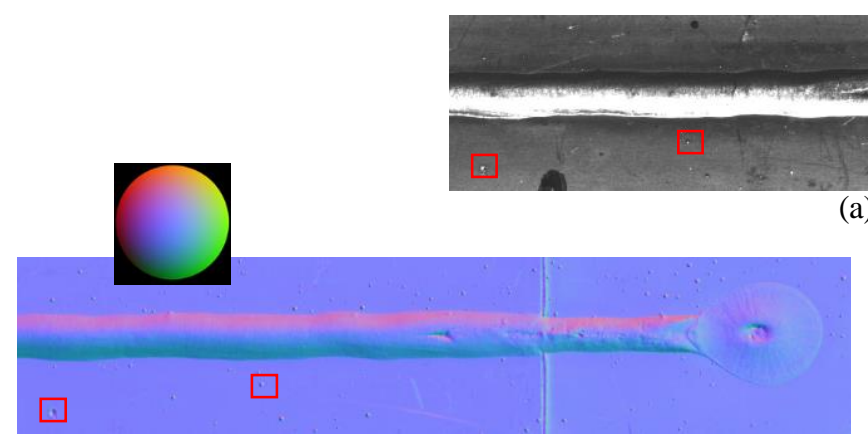

(b)

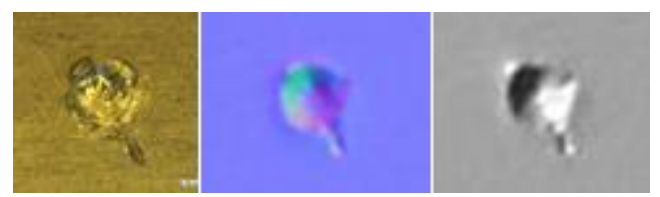

(d)

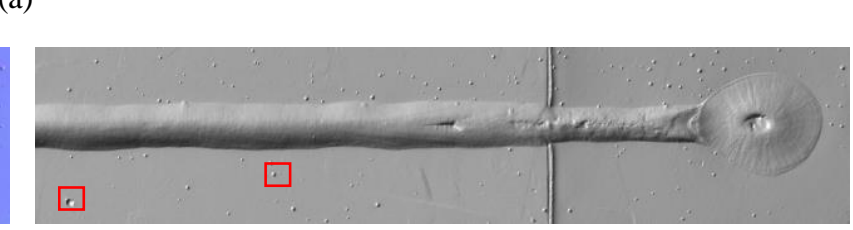

(c)

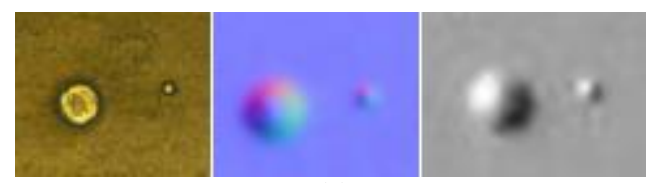

(e)

Fig. 16 Measurement results of Welding bead shape: (a) Original image, (b) Normal map, (c) 3D shape, (d) Close-up view of scratch, (e) Close-up view of welding spatter 


\section{文献}

Coleman, E.N. and Jain, R., Obtaining 3-dimensional shape of textured and specular surfaces using four-source photometry, Computer Graphics and Image Processing, Vol.18, Issue4 (1982), pp.309-328.

Hahn, D. V., Duncan, D. D., Baldwin, K. C., Cohen, J. D. and Purnomo, B., Digital hammurabi: design and development of a 3D scanner for cuneiform tablets, In Proceedings of SPIE, Vol.6056(2006), pp. 130-141.

Higo, T., Matsushita, Y., Joshi, N. and Ikeuchi, K., A hand-held photometric stereo camera for 3-D modeling, In proceedings of International Conference on Computer Vision (2009), pp.1234-1241.

肥後智昭, 宮崎大輔, 池内克史, センサフュージョンによる効率的な 3 次元モデルの推定と表現, 映像情報メディ ア学会誌, Vol.64, No.1 (2010), pp.112-119.

Horn, B. K. P. and Brooks, M. J., The variational approach to shape from shading, Computer Vision, Graphics, and Image Processing, Vol.33, No.2 (1986), pp.174-208.

Ikehata, S., Wipf, D., Matsushita, Y. and Aizawa, K., Robust photometric stereo using sparse regression, In proceedings of IEEE Conference on Computer Vision and Pattern Recognition (CVPR)(2012), pp.318-325.

岩永敏秀, 山本哲雄, 中村広隆, 照明用 LED モジュールの光学特性測定システムの開発, 東京都立産業技術研究 センター研究報告, No.2 (2007), pp.34-37.

Johnson, M. K., Cole, F., Raj, A. and Adelson, E. H., Microgeometry capture using an elastomeric sensor, ACM SIGGRAPH (2011).

Kamikawa, T., Miyazaki, D., Baba, M., Furukawa, R., Aoyama, M., Hiura, S. and Asada, N., High density shapes using photometric stereo and laser range sensor under unknown light-source direction, IAPR International Conference on Machine Vision Applications (2013), pp.125-128.

Luo, T., Shen, J. and Li, X., Accurate normal and reflectance recovery using energy optimization, IEEE Transactions on Circuits and Systems for Video Technology, Vol.25, No.2 (2015), pp.212-224.

Miyazaki, D., Hara, K. and Ikeuchi, K., Median photometric stereo as applied to the segonko tumulus and museum objects, International Journal of Computer Vision, Vol.86, Issue2-3 (2010), pp.229-242.

Mukaigawa, Y., Ishii, Y. and Shakunaga, T., Analysis of photometric factors based on photometric linearization, Journal of the Optical Science of America A, Vol.24, No.10 (2007), pp.3326-3334.

Nayar, S.K., Ikeuchi, K. and Kanade, T., Determining shape and reflectance of hybrid surfaces by photometric sampling, IEEE Transactions on Robotics and Automation, Vol.6, No.4 (1990), pp.418-431.

Nehab, D., Rusinkiewicz, S., Davis, J. and Ramamoorthi, R., Efficiently combining positions and normals for precise 3D geometry, In Proceedings of SIGGRAPH (2005), pp. 536-543.

Powell, M. W., A simple strategy for calibrating the geometry of light sources, IEEE Transactions on Pattern Analysis and Machine Intelligence, Vol.23, No.9 (2001), pp.1022-1027.

高松淳, 松下康之, 池内克史, 画像ノイズを用いたレスポンス関数の推定, 画像の認識・理解シンポジウム (MIRU) (2007), pp.189-196.

Tan, R.T. and Ikeuchi, K., Separating reflection components of textured surfaces using a single image, IEEE Transactions on Pattern Analysis and Machine Intelligence, Vol.27, Issue2 (2005), pp.178-193.

Vlasic, D., Peers, P., Baran, I., Debevec, P., Popovic, J., Rusinkiewicz, S. and Matusik, W., Dynamic shape capture using multi-view photometric stereo, ACM Transactions on Graphics, Vol.28, Issue5 (2009).

Woodham, R. J., Photometric method for determining surface orientation from multiple images, Optical Engineering, Vol.19, No.1 (1980), pp.139-144.

Wu, T. P., Sun, J., Tang, C. K. and Shum, H. Y., Interactive normal reconstruction from a single image, ACM Transactions on Graphics, Vol.27, No.5 (2008).

Yamaura, Y., Nanya, T., Imoto, H. and Maekawa, T., Shape reconstruction from a normal map in terms of uniform bi-quadratic B-spline surfaces, Computer-Aided Design, Vol.63 (2015), pp.129-144. 


\section{References}

Coleman, E.N. and Jain, R., Obtaining 3-dimensional shape of textured and specular surfaces using four-source photometry, Computer Graphics and Image Processing, Vol.18, Issue4 (1982), pp.309-328.

Hahn, D. V., Duncan, D. D., Baldwin, K. C., Cohen, J. D. and Purnomo, B., Digital hammurabi: design and development of a 3D scanner for cuneiform tablets, In Proceedings of SPIE, Vol.6056(2006), pp. 130-141.

Higo, T., Matsushita, Y., Joshi, N. and Ikeuchi, K., A hand-held photometric stereo camera for 3-D modeling, In Proceedings of International Conference on Computer Vision (2009), pp.1234-1241.

Higo, T., Miyazaki, D. and Ikeuchi, K., Efficient estimation and representation of 3D model with sensor fusion, Journal of the Institute of Image Information and Television Engineers, Vol.64, No.1 (2010), pp.112-119 (in Japanese).

Horn, B. K. P. and Brooks, M. J., The variational approach to shape from shading, Computer Vision, Graphics, and Image Processing, Vol.33, No.2 (1986), pp.174-208.

Ikehata, S., Wipf, D., Matsushita, Y. and Aizawa, K., Robust photometric stereo using sparse regression, In proceedings of IEEE Conference on Computer Vision and Pattern Recognition (CVPR)(2012), pp.318-325.

Iwanaga, T., Yamamoto, T. and Nakamura, H., Development of a measuring system of the photometry of LED modules, Bulletin of TIRI, No.2, (2007), pp.34-37 (in Japanese).

Johnson, M. K., Cole, F., Raj, A. and Adelson, E. H., Microgeometry capture using an elastomeric sensor, ACM SIGGRAPH (2011).

Kamikawa, T., Miyazaki, D., Baba, M., Furukawa, R., Aoyama, M., Hiura, S. and Asada, N., High density shapes using photometric stereo and laser range sensor under unknown light-source direction, IAPR International Conference on Machine Vision Applications (2013), pp.125-128.

Luo, T., Shen, J. and Li, X., Accurate normal and reflectance recovery using energy optimization, IEEE Transactions on Circuits and Systems for Video Technology, Vol.25, No.2 (2015), pp.212-224.

Miyazaki, D., Hara, K. and Ikeuchi, K., Median photometric stereo as applied to the segonko tumulus and museum objects, International Journal of Computer Vision, Vol.86, Issue2-3 (2010), pp.229-242.

Mukaigawa, Y., Ishii, Y. and Shakunaga, T., Analysis of photometric factors based on photometric linearization, Journal of the Optical Science of America A, Vol.24, No.10 (2007), pp.3326-3334.

Nayar, S.K., Ikeuchi, K. and Kanade, T., Determining shape and reflectance of hybrid surfaces by photometric sampling, IEEE Transactions on Robotics and Automation, Vol.6, No.4 (1990), pp.418-431.

Nehab, D., Rusinkiewicz, S., Davis, J. and Ramamoorthi, R., Efficiently combining positions and normals for precise 3D geometry, In Proceedings of SIGGRAPH (2005), pp. 536-543.

Powell, M. W., A simple strategy for calibrating the geometry of light sources, IEEE Transactions on Pattern Analysis and Machine Intelligence, Vol.23, No.9 (2001), pp.1022-1027.

Takamatsu, J., Matsushita, Y. and Ikeuchi, K., Determining radiometric response functions from image-noise variance, Meeting on Image Recognition and Understanding (MIRU) (2007), pp.189-196 (in Japanese).

Tan, R.T. and Ikeuchi, K., Separating reflection components of textured surfaces using a single image, IEEE Transactions on Pattern Analysis and Machine Intelligence, Vol.27, Issue2 (2005), pp.178-193.

Vlasic, D., Peers, P., Baran, I., Debevec, P., Popovic, J., Rusinkiewicz, S. and Matusik, W., Dynamic shape capture using multi-view photometric stereo, ACM Transactions on Graphics, Vol.28, Issue5 (2009).

Woodham, R. J., Photometric method for determining surface orientation from multiple images, Optical Engineering, Vol.19, No.1 (1980), pp.139-144.

Wu, T. P., Sun, J., Tang, C. K. and Shum, H. Y., Interactive normal reconstruction from a single image, ACM Transactions on Graphics, Vol.27, No.5 (2008).

Yamaura, Y., Nanya, T., Imoto, H. and Maekawa, T., Shape reconstruction from a normal map in terms of uniform bi-quadratic B-spline surfaces, Computer-Aided Design, Vol.63 (2015), pp.129-144. 